\title{
Uniform climate development between the subtropical and subpolar Northeast Atlantic across marine isotope stage 11
}

\author{
J. P. Helmke ${ }^{1, *}$, H. A. Bauch ${ }^{1,2}$, U. Röhl ${ }^{3}$, and E. S. Kandiano ${ }^{1}$ \\ ${ }^{1}$ Leibniz Institute of Marine Sciences, Wischhofstr. 1-3, 24148 Kiel, Germany \\ ${ }^{2}$ Academy of Sciences, Humanities and Literature, Geschwister-Scholl-Str. 2, 55131 Mainz, Germany \\ ${ }^{3}$ University of Bremen, Postfach 330440, 28334 Bremen, Germany \\ *now at: Helmholtz Centre for Environmental Research - UFZ, Permoserstr. 15, 04318 Leipzig, Germany
}

Received: 12 March 2008 - Published in Clim. Past Discuss.: 9 April 2008

Revised: 10 June 2008 - Accepted: 6 August 2008 - Published: 1 September 2008

\begin{abstract}
Proxy records from a core site off Northwest Africa were generated and compared with data from the subpolar Northeast Atlantic to unravel some main climatic features of interglacial marine isotope stage (MIS) 11 (423$362 \mathrm{ka}$ ). The records point to an almost $25 \mathrm{kyr}$ lasting full interglacial period during stage 11 that was preceded by a considerably long glacial-interglacial transition (Termination V). Off NW Africa, a strong reduction of terrestrially derived iron input is noted after $420 \mathrm{ka}$ suggesting a pronounced increase in continental humidity and vegetation cover over Northwest Africa. In analogy to the Holocene climate of the region, this early wet phase of MIS 11 was likely associated with enhanced influence of the West African monsoon system on the Saharan-Sahel region which led to both a reduction in trade wind intensity off NW Africa and the formation of sapropel S11 in the Mediterranean Sea. A detailed comparison with data from the subpolar North Atlantic indicates a remarkable coherent timing for the main environmental changes in both regions giving evidence for strong interglacial climate connection between the low and high latitude North Atlantic. Although our records of MIS 11 compare well with the Holocene in terms of some major climate characteristics there are distinct differences in the temporal evolution of each peak warm interval. This suggests that care should be taken when using MIS 11 as analogue to forecast future interglacial conditions.
\end{abstract}

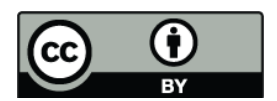

Correspondence to: J. P. Helmke (jan.helmke@ufz.de)

\section{Introduction}

Unravelling the climatic conditions of interglacial marine isotope stage (MIS) 11, a warm period centered around 400000 years ago, has gained increasing attention from the community of paleoclimatologists over recent years. Because the insolational forcing during MIS 11 was similar to the present time and the near future, MIS 11 has been suggested to be the best Pleistocene interglacial analogue, allowing to predict the duration of the current interglacial (Berger and Loutre, 1996; Loutre, 2003). Data from various climate archives point to climate conditions during interglacial stage 11 that seem to be close to the Holocene situation: For instance, in the South Atlantic and the Pacific sea-surface temperatures (SSTs) were comparable (Hodell et al., 2000; King and Howard, 2000), global sea level was similar (Bauch and Erlenkeuser, 2003; McManus et al., 2003) or even of higher magnitude (Hearty et al., 1999) and concentration of greenhouse gases show the same range (EPICA Community Members, 2004). However, paleoceanographic evidence from the North Atlantic is ambiguous: Some studies record rather similar conditions during MIS 11 and the Holocene (e.g. Oppo et al., 1998; McManus et al., 2003; de Abreu et al., 2005) while other studies using deep-sea records from sites of the polar and subpolar North Atlantic regions indicate colder conditions during the warmest interval of MIS 11 when directly compared to the Holocene (e.g. Bauch et al., 2000; Bauch and Erlenkeuser, 2003; Helmke and Bauch, 2003). Hence, the analogy between the climate conditions of MIS 11 and the Holocene is questioned and interglacial differences in the meridional temperature gradient between the north-polar region and the mid-northern latitudes are

Published by Copernicus Publications on behalf of the European Geosciences Union. 


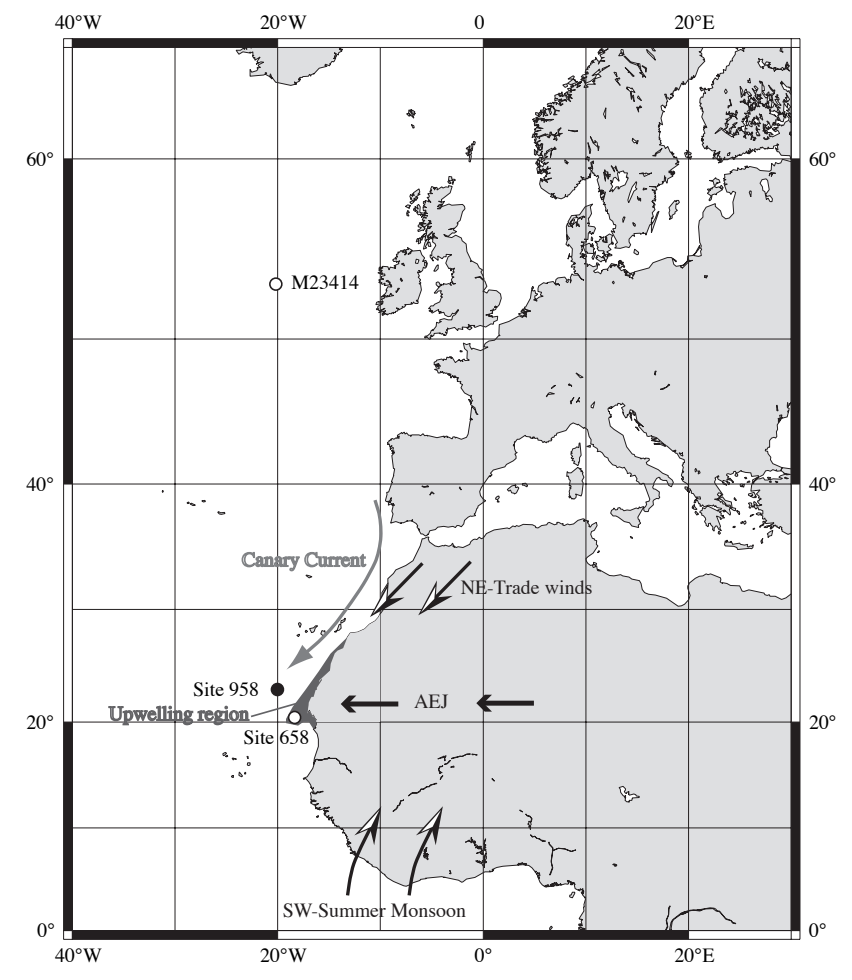

Fig. 1. Geographical position of investigated core (Site 958, indicated with black circle) and discussed reference sites (M23414, $53^{\circ} \mathrm{N}, 20^{\circ} \mathrm{W}$ and Site $658,20^{\circ} \mathrm{N}, 18^{\circ} \mathrm{W}$, indicated with white circles). Main features of Northwest African wind system (NE-Trade winds, SW-Summer Monsoon and African Easterly Jet (AEJ), see text for details) are sketched (wind directions are denoted by arrows). Gray arrow indicates position and direction of the Canary Current. Area marked in dark gray denotes the Northwest African coastal upwelling region.

suggested. This notion is fueled by recent studies which point to systematic differences in the type of atmospheric-oceanic circulation over the Northeast Atlantic region during major interglacial intervals (Bauch and Kandiano, 2007; Kandiano and Bauch, 2007), emphasizing the need for additional studies on the regional climatic development of MIS 11 in crucial areas of the North Atlantic sector.

In this study, we present a multi-proxy deep-sea sediment record off Northwest Africa in order to reconstruct the lowlatitude MIS 11 climate signal from the Northeast Atlantic in much greater detail than previously described (e.g. deMenocal, 1995; Pflaumann et al., 1998). Our record allows us to characterize the changes in deep as well as in surface water conditions of the subtropical East Atlantic across MIS 11 and to link the variations in eolian dust input from the Saharian desert, i.e. the degree of continental aridity, to the strength of the northeast trade winds and the West African Monsoon system. Because the prevaling intensity of this wind system depends on the particular temperature gradient between the cold polar and warm subtropical regions we will be interpret-

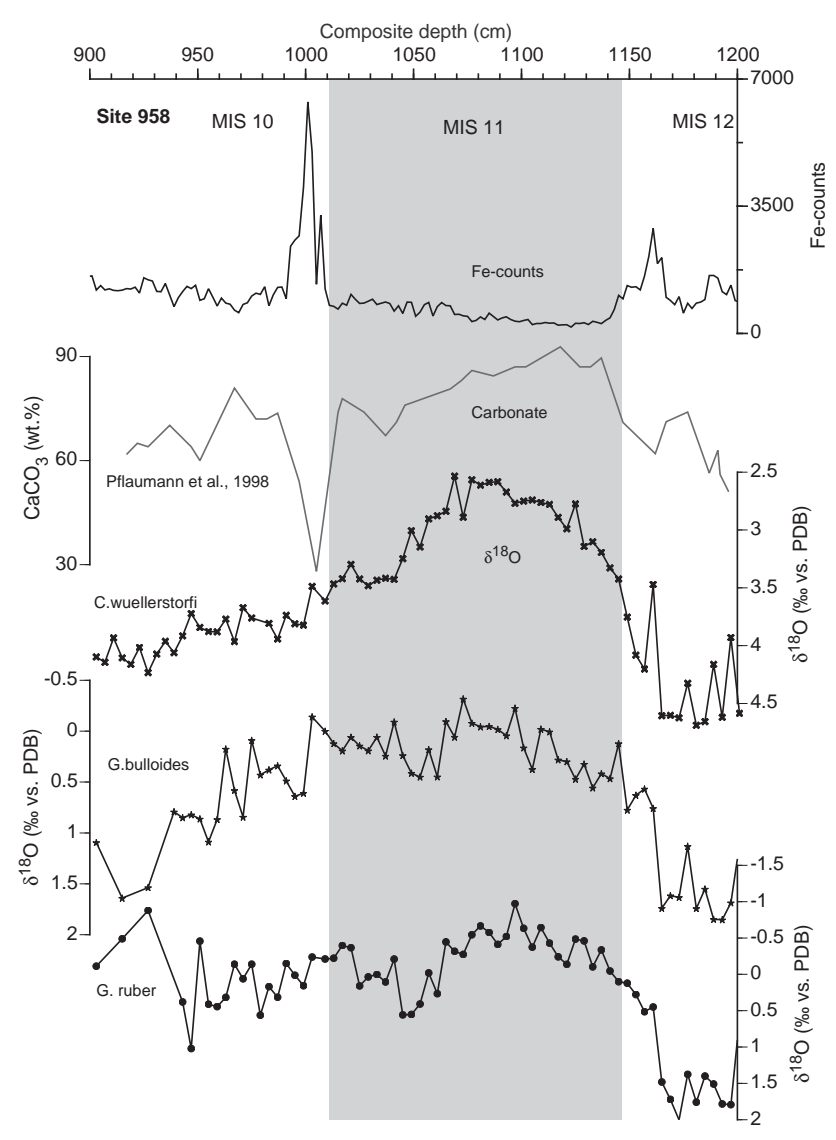

Fig. 2. Site 958 downcore variations of (from top to bottom) Fecounts, carbonate content (\%, data taken from Pflaumann et al., 1998), benthic oxygen isotopes (C. wuellerstorfi) and planktic oxygen isotope values of $G$. bulloides and G. ruber between 900 and $1200 \mathrm{~cm}$ core depth. For details about methods and composite core depth at Site 958 see text. The MIS 11 interval is marked in light gray color.

ing the climatic development of MIS 11 at the low latitudes by comparing it to a corresponding record from the subpolar North Atlantic.

\section{The Core material, methods and chronology}

Several sedimentological and geochemical parameters from ODP Site 958 (Fig. $1,23^{\circ} \mathrm{N}$ and $20^{\circ} \mathrm{W} ; 3795 \mathrm{~m}$ water depth) off Northwest Africa were investigated to reconstruct the characteristics of MIS 11 in the low-latitude Atlantic (Fig. 2). Benthic and planktic ${ }^{18} \mathrm{O}$ (given as per mil deviations relative to the Pee Dee Belemnite (PDB) carbonate standard) were sampled at a resolution of $4 \mathrm{~cm}$ between MIS 10 and 12. As the ice volume component of the benthic ${ }^{18} \mathrm{O}$ appears to be global (Shackleton, 1967), the benthic isotopes from Site 958 are used for correlation with the SPECMAP stack of benthic ${ }^{18} \mathrm{O}$ (Imbrie et al., 1984) to generate an age model for the study site. The ${ }^{18} \mathrm{O}$ records of planktic 
foraminifers reflect the variability of surface water hydrography, i.e. the temperature of the water in which the shell was secreted as well as local salinity changes. All oxygen isotopes were measured at the Stable Isotope Mass Spectrometer Laboratory at the IFM-GEOMAR with the Finnigan MAT 252 mass spectrometer system. On average, 5 specimens of the epifaunal benthic foraminifer Cibicidoides wuellerstorf from the size fraction $250-500 \mu \mathrm{m}$ and 15 specimens of the planktic foraminifers Globigerinoides ruber (white) and Globogerinoides bulloides were taken for each analysis. Whereas $G$. ruber mainly reflects summer surface conditions (Ganssen and Kroon, 2000), G. bulloides indicates in the lower latitudes more temperate and colder conditions of surface water masses. Iron $(\mathrm{Fe})$ concentrations in the sediment as a proxy for aeolian input to the core site were measured on the half core in $2 \mathrm{~cm}$ steps using the X-ray fluorescence (XRF) corescanner (Röhl and Abrams, 2000; Haug et al., 2001) at the University of Bremen, Germany.

Depth correction for Site 958 was assigned following the splice between Holes 958A and 958B as previously described by Pflaumann et al. (1998). The age model was established by synchronizing the $C$. wuellerstorfi oxygen isotope data across MIS 11 to the standard SPECMAP chronology (see Fig. 3; Imbrie et al., 1984). We used SPECMAP ages of events between substages 10.2 and 12.2 as reference points and applied linear interpolation of ages between all age model tie points. The average sedimentation rates of $2.4 \mathrm{~cm} / \mathrm{kyr}$ during MIS 11 are comparable to the general late Pleistocene values observed at Site 958 (Firth et al., 1996; Pflaumann et al., 1998). Hence, the temporal resolution of the proxy records varies between $1 \mathrm{kyr}$ for the XRF record and $2 \mathrm{kyr}$ for records of both benthic and planktic isotopes, which enables us to record the MIS 11 climate evolution in the study region.

Interglacial MIS 11 records from subtropical Site 958 will be compared with MIS 11 data from the subpolar Northeast Atlantic region (M23414; data from Helmke and Bauch, 2003 and Kandiano and Bauch, 2007). For a better comparison with the Site 958 records we altered the recent age model from the latter (Kandiano and Bauch, 2007). Hence, as for Site 958, the age model of M23414 is based on correlating ${ }^{18} \mathrm{O}$ records (C. wuellerstorfi and $G$. bulloides) to the SPECMAP chronology using events between 10.2 and 12.2. as tie points (see Fig. 3).

\section{Results}

\subsection{Development of interglacial MIS 11}

The poorly resolved pre-existing planktic oxygen isotope and carbonate content data from Site 958 (Pflaumann et al., 1998) have been used to identify the MIS 11 interval within the drilled sediment sections. The much higher resolved new results of benthic and planktic oxygen isotopes as well as

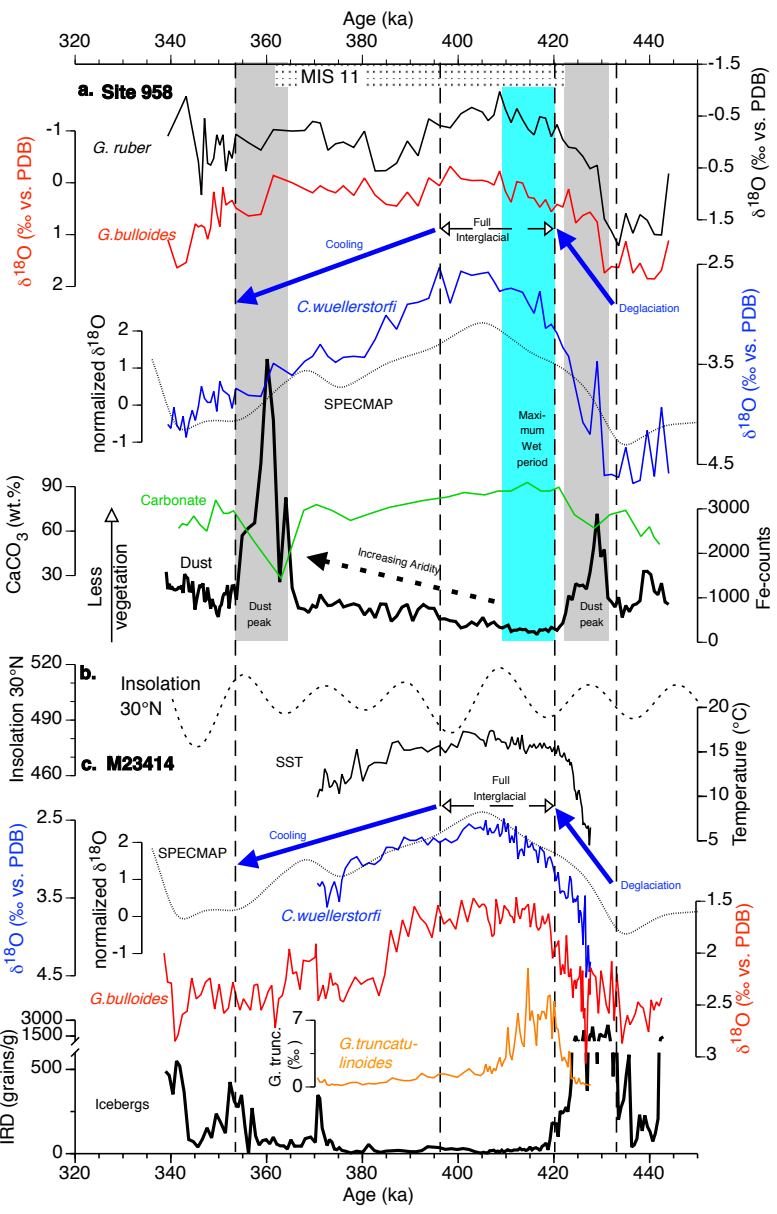

Fig. 3. (a) Proxy records of ODP Site 958 vs. age. From top to bottom planktic (G. ruber and G. bulloides) and benthic $\delta^{18} \mathrm{O}$ (C. wuellerstorfi), carbonate content data and $\mathrm{Fe}$-counts are shown. Black dotted line denotes SPECMAP record and reference ages between 335 and $450 \mathrm{ka}$, further details about the age model are given in the text. The MIS 11 interval between 423 and $362 \mathrm{ka}$ is denoted. The full interglacial interval within MIS 11, the glacialinterglacial termination from MIS 12 and the cooling trend during late MIS 11 are marked by stippled lines and indicated with arrows. The maximum wet period of MIS 11 and dust peaks during early and late MIS 11 are shaded. (b) Evolution of summer solstice insolation at $30^{\circ} \mathrm{N}$ (Berger, 1978) between 340 and $440 \mathrm{ka}$. (c) Records of site M23414 vs. age. Black dotted line denotes SPECMAP record and reference ages between 335 and $450 \mathrm{ka}$, further details about the age model are given in the text. From top to bottom planktic foraminiferal SST (average summer values derived from different mathematical approaches - MAT, TFT, RAM, see Kandiano and Bauch (2007) for methodological details), benthic $\delta^{18} \mathrm{O}$ (C. wuellerstorfi), planktic $\delta^{18} \mathrm{O}$ (G. bulloides), relative abundance of $G$. truncatulinoides and content of iceberg-rafted material from the size fraction $>150 \mu \mathrm{m}$ are shown. The characteristics of MIS 11 at Site 958 (deglaciation, full interglacial interval and cooling phase) are also denoted for M23414 to illustrate the close coherence of interglacial climate evolution between the lower (Site 958) and the higher (M23414) latitudes (see text for details). 
XRF measurements (Fig. 2) were used to gain insight into the succession of environmental conditions in the subtropical East Atlantic during this interglacial interval. Full interglacial conditions, i.e. the peak warm interval of MIS 11 (age range 420-396 ka), can be clearly identified in the Site 958 proxy records by low benthic (C. wuellerstorfi $2.54 \%$ ) and planktic isotope (G. bulloides $-0.32 \%$; G. ruber $-0.97 \%$ ) values together with a high carbonate content and a low iron concentration in the sediment (see Fig. 3a).

The interglacial periods within the Late Pleistocene glacial-interglacial climate system are always preceded by so-called terminations, i.e. abrupt transitions from the cold climate mode to warm interglacial climate conditions (e.g. Broecker and van Donk, 1970). During Termination V, the deglacial transition from MIS 12, all proxy records are characterized by large-scale changes between the pronounced glacial conditions of MIS 12.2 at $434 \mathrm{ka}$ and the first occurrence of full interglacial conditions in MIS 11 at about 420 ka (Fig. 3a). Benthic isotopes of $C$. wuellerstorf decrease by about $1.5 \%$, planktic isotope values decrease by about $2 \%$ o in G. ruber and by about $1 \%$ in G. bulloides, The carbonate content remains below $75 \%$ during Termination $\mathrm{V}$ and increases up to values around $90 \%$ with the onset of the full interglacial period. Contemporaneously the iron concentration reveals inverse changes with a pronounced maximum of iron input during late Termination V between 430 and $423 \mathrm{ka}$, which is followed by a rapid decrease of values towards minimum iron concentrations at around $420 \mathrm{ka}$.

Both, the carbonate content and the iron concentration do not change significantly for the next about $11 \mathrm{kyr}$. The carbonate content remains high, i.e. it is characterized by maximum values of about $90 \%$. At the same time the iron concentration constantly shows its lowest values within the analyzed core section (see Fig. 3a). The benthic and planktic oxygen isotope values further decrease between about $0.5-0.8 \%$ o during this early full interglacial part. After about $409 \mathrm{ka}$ the planktic and benthic oxygen isotope records exhibit plateaulike minimum values until about $396 \mathrm{ka}$ (Fig. 3a). In parallel, the carbonate content continuously decreases, and the iron counts increase notably with a prominent rise after $396 \mathrm{ka}$.

After $396 \mathrm{ka}$, all parameters indicate changing trends towards the end of MIS 11 and further into the ensuing glacial period of MIS 10 (Fig. 3a). During late MIS 11 the benthic C. wuellerstorfi isotope values show an about $1 \%$-increase. The planktic records do in general also show increasing interglacial values during the later MIS 11 despite some variability in the detailed evolution of the benthic and planktic isotope records. Iron concentrations rise continuously during the later part of MIS 11 with a massive iron peak in the early part of MIS 10 around $360 \mathrm{ka}$. This huge iron peak goes along with a significant drop in carbonate content to minimum values of only $28 \%$.

\section{Discussion}

\subsection{Termination V}

The glacial-interglacial transition from MIS 12 to MIS 11 lasted about $15 \mathrm{kyr}$ and was characterized by large-scale shifts of all proxy records, which extend into the early MIS 11 before typical full interglacial conditions can be recognized (Fig. 3a). The benthic carbon isotope record from neighbouring Site 658 (Fig. 1; Sarnthein and Tiedemann, 1990) gives support for prominent changes across Termination V, i.e. a major breakdown in bottom water ventilation with incursion of Antarctic water masses into the subtropical East Atlantic and a major Heinrich-style event is indicated. These observations about the character of Termination $\mathrm{V}$ from the low-latitude East Atlantic are in line with previous results from other marine records indicating that in the Northern Hemisphere MIS 12 was an extremely pronounced glacial climate period (e.g. Rohling et al., 1998; Helmke and Bauch, 2003; Billups et al., 2006), which terminated in a long-lasting glacial-interglacial transition of much higher amplitude than the later Pleistocene terminations (Oppo et al., 1998; Bauch et al., 2000; Thunell et al., 2002; Kandiano and Bauch, 2007).

\subsection{Subtropical wind system and interglacial climate}

The massive cessation of iron counts at around $420 \mathrm{ka}$ indicates the abrupt end of terrigenous input into in subtropical East Atlantic immediately after the end of the glacial termination. Due to the offshore position of Site 958 about $380 \mathrm{~km}$ from Northwest Africa (Fig. 1) and the lack of major river mouths at the adjacent Saharan coastline it is rather unlikely that fluvial sediments contribute to the terrigenous component of the core material. Indeed, past grain size analyses have proven the eolian origin of the late Pleistocene terrigenous matter at Site 958 and other neighbouring drill sites (Tiedemann et al., 1994; Pflaumann et al., 1998). Therefore, the terrigenous input to our core site is primarily linked to the variability of the wind system in subtropical Northern Africa, and hence, to climate. The iron concentration of the sediment is a reliable tool to trace this variability: The dust flux at the study region comes from two main source areas, either from the lateritic South Sahara and the Sahel zone containing ironstained material (Parkin and Shackleton, 1973; Lange, 1982; Sarnthein, 1982) or from the Northern Sahara and coastal areas containing pale quartz grains that lack iron (Koopmann, 1979; Lange, 1982). It has been shown that an iron-rich terrigenous dust supply to the study region generally dominates during cold climate modes (Balsam et al., 1995; Pflaumann et al., 1998).

Currently Northern Africa is characterized by strong seasonality in rainfall and wind directions. During the dry winter months the Northeast trade winds dominate the area (Hastenrath, 1985; Stuut et al., 2005) and, consequently, Saharan 
and sub-Saharan soil is transported to the core site (Fig. 1). The northward movement of the Intertropical Convergence Zone and the onset of the West African monsoon in summer increase the seasonal moisture flux in tropical western Africa through southwest surface winds from the East Atlantic. During this period of reduced trade winds the eolian transport to the subtropical East Atlantic is mainly caused by the Saharan dust plume, which carries West Saharan mineral dust at mid-tropospheric levels westward via the so-called African Easterly Jet (Fig. 1; Carlson and Prospero, 1972; Schütz et al., 1981; Prospero and Lamb, 2003). Previous studies have indicated that wind speed over the East Atlantic and aridity over Northwest Africa increased significantly during Pleistocene glacial times (e.g. Parkin and Shackleton, 1973; Sarnthein et al., 1982; Tiedemann et al., 1994; Matthewson et al., 1995). Thus, the pelagic sediments off Northwest Africa reveal a clear pattern of maximum glacial and minimum interglacial wind driven terrigenous input (Tiedemann et al., 1994; Pflaumann et al., 1998) that mirrors the large-scale variations in North African aridity parallel to the high latitude changes between Pleistocene cold and warm climate modes (Parkin and Shackleton, 1973; Sarnthein et al., 1981; Ruddiman and Janecek, 1989; deMenocal, 1995).

The drop of terrigenous input into the sediment after the termination points to a rapid increase in moisture flux over Northwest Africa, which is most likely related to a generally stronger monsoon over West Africa. The minimum iron concentrations between about 420 and 409 ka (Fig. 3a) characterize this interval as the peak-wet period of the entire interglacial MIS 11. The high values in carbonate content parallel to the maximum humidity cannot be interpreted as a simple result of a contemporaneous peak carbonate flux. The carbonate and the iron content records mirror each other to a large part during the investigated interval indicating that the carbonate signal is diluted by the terrigneous input and not a pure productivity signal. Moreover, it has to be considered that changes in carbonate dissolution may also have influence on the carbonate record. Site 958 was drilled at about $3800 \mathrm{~m}$ water depth, were off Northwest Africa the more ventilated North Atlantic water masses have on shorter time scales been replaced by more corrosive Antarctic bottom waters during Pleistocene times (e.g. Sarnthein and Tiedemann, 1990). During the later part of the full interglacial period the notably increasing terrigenous input off the African coast after $409 \mathrm{ka}$ (Fig. 3a) documents the end of peak wet conditions. However, based on the iron counts still rather humid conditions probably continued until the end of the full interglacial interval at about $396 \mathrm{ka}$ (Fig. 3a). An African wet period during MIS 11 as it is evident from the low iron counts of Site 958 corresponds well to the reconstructions of Holocene climate conditions in the region (Gasse et al., 1990; Kutzbach and Liu, 1997; Jolly et al., 1998; Gasse, 2000). Data from ODP Site 658 (Fig. 1) indicate that a Holocene wet period across Northwestern Africa, the so-called "African humid period", started after the end of the Younger Dryas at around
$12 \mathrm{ka}$ and lasted for about $6.5 \mathrm{kyr}$ (deMenocal et al., 2000a, b; Adkins et al., 2006). Although the establishment of pronounced wet periods during MIS 11 and the Holocene suggests similar interglacial climate characteristics in the subtropical North Atlantic, the succession of both humid intervals seems to have been different. Site 958 shows the minimum dust input during the early wet period and prior to the maximum insolation (Fig. 4a), In contrast, at Site 658 the lowest terrigenous input during the "African humid period" is observed within the early middle Holocene some thousand years after the first occurrence of wet conditions in subtropical Northwest Africa and after the maximum in Holocene insolation (Fig. 4b). The establishment of peak wet conditions during the middle Holocene is also known from other North African and West African study regions (Hillaire et al., 1983; Gasse, 2000; Weldeab et al., 2007). It is further indicated that the pronounced humid conditions of MIS 11 lasted about 11 kyrs, considerably longer than the maximum wet phase of the Holocene "African humid period" over Northwestern Africa.

\subsection{Mediterranean sapropels}

Wet conditions during the Holocene and MIS 11 occurred in parallel to the formation of sapropel layers (S) in the Mediterranean Sea. Increased humid conditions of the Holocene at Site 658 are noticed at times of sapropel S1 (Fig. 4; Adkins et al., 2006). The Mediterranean sapropel $S 11$ is yet not well constrained stratigraphically and has previously been dated to occur around $407 \mathrm{ka}$ (Kroon et al., 1998; Lourens, 2004). Thus, S11 seems to correspond quite well to the enhanced wet conditions over Northwest Africa during early MIS 11 (Fig. 4). Increased African interglacial humidity would lead to higher run-off from the African continent and, subsequently, to a higher freshwater input into the Mediterranean Sea. This may enhance sapropel formation in two ways: It could give rise to a low-salinity surface water cap that impedes circulation with bottom waters or the freshwater input may increase the boundary between depleted surface and nutrient-rich intermediate waters and, thus, enhance marine productivity. Regardless of the process to explain the specificities behind sapropel formation in the Mediterranean Sea, our results strongly suggest a close link between the wind-driven system off NW Africa and the terrestrial conditions over Northern Africa.

\subsection{Subtropical surface oceanography}

The oxygen isotope records of the two species $G$. ruber and $G$. bulloides provide details about the regional water mass characteristics, i.e. they reflect the $\delta^{18} \mathrm{O}$ of seawater and, therefore, record the regional salinity and temperature signals of the near surface ocean. According to Ganssen (1983) $\delta^{18} \mathrm{O}$ of $G$. ruber reflects along the Northwest African upwelling belt summer temperatures, whereas the $\delta^{18} \mathrm{O}$ of $G$. bulloides 

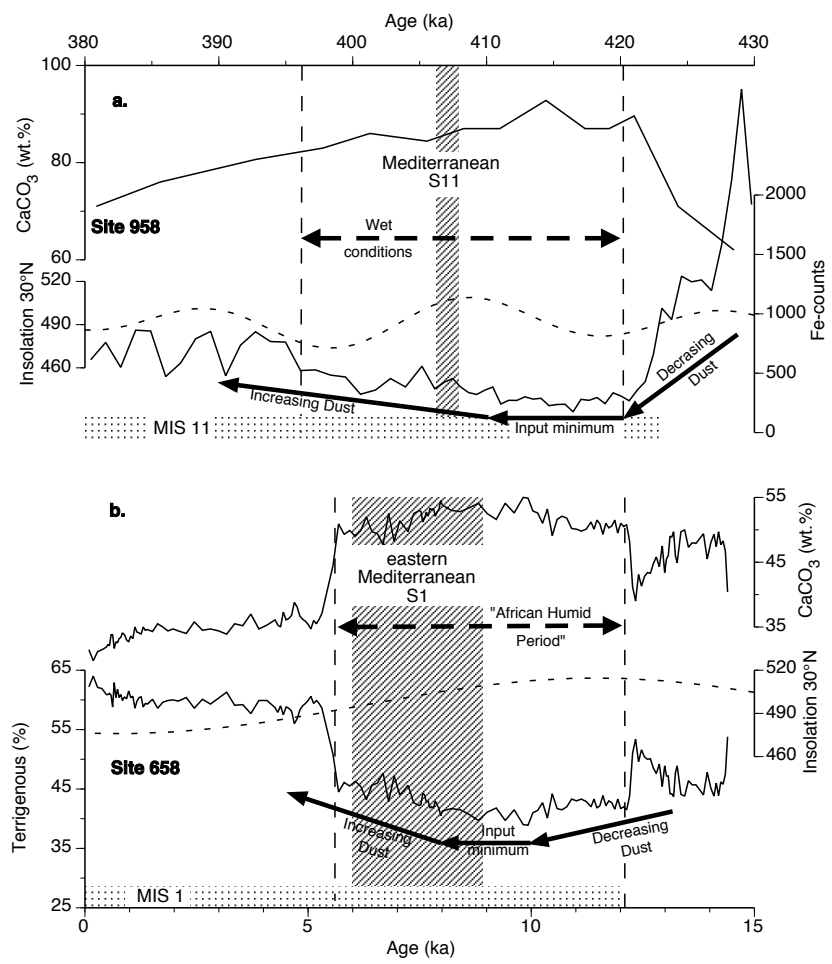

Fig. 4. Comparison of interglacial wet periods from MIS 11 and the Holocene showing data from (a) Site 958 (carbonate content and $\mathrm{Fe}$-counts between 430 and $380 \mathrm{ka}$ ) alongside with the insolation at $30^{\circ} \mathrm{N}$ at that time (after Berger, 1978) and (b) Site 658 (carbonate content and Terrigenous (\%) between 15 and $0 \mathrm{ka}$, data from deMenocal et al., 2000) alongside with the insolation at $30^{\circ} \mathrm{N}$ at that time (after Berger, 1978). The "African Humid Period" at Site 658 (deMenocal et al., 2000; Adkins et al., 2006) and the interval of pronounced wet conditions during MIS 11 at Site 958 are indicated by stippled vertical lines and stippled arrows. General trends of interglacial dust input to the core sites during MIS 11 and the Holocene are marked by black arrows. Positions of eastern Mediterranean sapropels S1 (age range according to Rohling et al., 1997, and Mercone et al., 2001) and S11 (age range according to Kroon et al., 1998, and Lourens, 2004) are indicated. Please note different age range of the data shown for MIS 11 (a) and MIS 1 (b).

document in this region surface temperatures during times of active upwelling. The changes in the surface water conditions at Site 958, which was drilled outside the upwelling area (see also Fig. 1, are mainly due to a more or less vigorous influence of the southward flowing Canary Current, which carries cool water masses to the core site that have previously been upwelled in the coastal belt off Northwest Africa (Johnson and Stevens, 2000). Hence, the planktic $\delta^{18} \mathrm{O}$ at Site 958 should most likely reflect the dynamics of the Canary Current and/or of the intensity of the wind-driven coastal upwelling system (Fig. 1). The overall $\delta^{18} \mathrm{O}$ changes during MIS 11 run parallel to the main changes of terrigenous input, e.g. full interglacial MIS 11 with its minimum dust input is associated with the lowest planktic isotope val- ues. This $\delta^{18} \mathrm{O}$ peak during times of increased moisture flux over Northwest Africa (Fig. 3) can be explained by enhanced monsoonal influence in the Saharan and the Sahel zone and maximum progradation of warm tropical surface waters into the subtropical regions as well as reduced upwelling intensity during full interglacial times.

4.5 Low and high latitude records and comparison of MIS 11 and 1

A comparison of Site 958 with records of core M23414 from the Rockall Plateau in the subpolar Northeast Atlantic (Fig. 1) shows strong similarities in the overall climatic evolution of MIS 11 (Fig. 3). We select M23414 for our comparison between the low and the high latitude Northeast Atlantic. The sediments of M23414 currently underlie the western edge of the North Atlantic Drift and, hence, capture past flow deflections and changes in the northward warm water advection during interglacial periods. The rather long duration of full interglacial conditions of more than $20 \mathrm{kyrs}$ at sites 958 and M23414 can also be observed at other sites in the subtropical (e.g. Healey and Thunell, 2004; Billups et al., 2004) as well as in the subpolar North Atlantic (e.g. Oppo et al., 1998; McManus et al., 2003). Moreover, at both sites the full interglacial conditions are characterized by the parallel succession of two clearly distinguishable periods: Immediately after the ending of deglacial processes, i.e. the terrigenous input via iceberg-rafting at higher latitudes and via dust at lower latitudes ceased, full interglacial conditions became established. This peak humidity off Northwest Africa during the early full interglacial period occurred in parallel to a pronounced maximum in the occurrence of the subtropical, deep-dwelling planktic foraminifer $G$. truncatulinoides at site M23414 (Fig. 3), pointing to a linkage between low-latitude hydrological changes and subtropical water mass advection into the subpolar North Atlantic. The planktic foraminiferal assemblage data from M23414 also clearly indicate that SSTs in the Northeast Atlantic continued to rise during this early phase of the full interglacial period, in line with the decreasing planktic and benthic $\delta^{18} \mathrm{O}$ values at both sites. It was only after $409 \mathrm{ka}$ that proxy data from both study sites would indicate peak interglacial conditions with maximum SSTs in the eastern Atlantic. Because this thermal maximum in the surface waters was coincident with lowest benthic oxgygen isotopes, it also implies the time of highest sea-level stand und lowest global ice volume during MIS 11. Peak interglacial conditions persisted until about $396 \mathrm{ka}$, and during times of low insolation forcing (Fig. 3b; Berger, 1978). In contrast, several studies from the North Atlantic region have shown that the Holocene climatic optimum, i.e. the peak warm period of the recent interglacial period occurred in the early to middle Holocene (e.g. Bond et al., 1997; Marchal et al., 2002; Andersen et al., 2004). This was a time of relatively high summer insolation in the high-latitude Northern Hemisphere (Koc et al., 1993; Bauch 
et al., 2001) and increased humidity over Northwest Africa (deMenocal et al., 2000; Gasse, 2000).

Results from other regions, e.g. marine proxy records from the polar North Atlantic (Bauch et al., 2000) or Antarctic ice core data of atmospheric gas concentrations (EPICA Community Members, 2004; Siegenthaler et al., 2005) confirm a rather late establishment of maximum warm conditions within interglacial MIS 11. These high northern and high southern latitudes sites also indicate that with the end of peak warm conditions during MIS 11 a rapid decline of interglacial climate and the subsequent development of glacial conditions can be recognized, and, thus, support the discussed results from the subpolar and the subtropical North Atlantic. This characteristic evolution of MIS 11 with a pronounced deglacial termination from the preceding cold period and a warm phase during the later part of the interglacial interval has to be considered for the ongoing discussion of possible climatic analogies between MIS 11 and the Holocene, especially when MIS 11 data are aligned to records of the present interglacial. This is important for the current debate as to whether the Holocene will remain stable for the millennia to come (EPICA Community Members, 2004; Broecker and Stocker, 2006) or whether the natural glacial inception of the Holocene has not yet occurred due to anthropogenic activity (Ruddiman, 2003, 2005). Proponents of both opinions argue with a comparison of the Holocene and the MIS 11 climates. However, most importantly, their alignment of certain time intervals from both interglacial periods differ from each other. Our new Site 958 record of subtropical MIS 11 climate evolution support previous studies by Crucifix and Berger (2006) and Kandiano and Bauch (2007). These would indicate that it seems rather inappropriate to incorporate and align the long deglacial interval of MIS 12 and early MIS 11 alongside with the elapsed $10 \mathrm{kyr}$ of the Holocene - as suggested by EPICA Community Members (2004) and Broecker and Stocker (2006) - in order to demonstrate interglacial climate analogies. The growing body of evidence from different climate archives now seems to suggest that MIS 11 might not be the best Late Pleistocene equivalent to the Holocene climate at all, neither on the basis of its orbital parameters nor of its regional environmental characteristics (Ruddiman, 2007).

It has been suggested that a considerably longer duration of Termination $\mathrm{V}$ compared to Termination I was largely responsible for this contrasting climate development during the early stages of MIS 1 and MIS 11 (Bauch and Erlenkeuser, 2003; Kandiano and Bauch, 2007). At both sites, 958 and M23414, the records indicate a rather synchronous return towards increasingly cooler conditions around $396 \mathrm{ka}$. At the Rockall Plateau, decreasing SSTs go along with a first recurrence of IRD, whereas in subtropical East Atlantic, the significant increase in planktic oxygen isotope values coincides with a noticeable increase in Saharan dust input. This synchroneity in the onset of climate deteriorations between the two regions during the later MIS 11 is thus evidence for teleconnections between the interglacial development of the higher and the lower latitudes. One may therefore conclude that the steepness of the poleward temperature gradient over the North Atlantic sector plays a major role for the precipitation and wind regime over NW Africa.

\section{Summary and conclusions}

The characteristics of interglacial stage 11 in the subtropical East Atlantic were studied using deep-sea sediments from an ODP-Site off Northwest Africa. The results demonstrate that the termination of the preceding glacial conditions continued into early MIS 11 before full interglacial conditions appeared at about $420 \mathrm{ka}$. Full interglacial conditions lasted for more than $20 \mathrm{kyr}$. They were during the early part associated with a pronounced humid period over Northwest Africa, which usually relates to an intensification of the West African monsoon system and, subsequently, a widespread vegetation cover over the Saharan and the Sahel zone. The occurrence of an interglacial wet period in Northwestern Africa during MIS 11 is comparable to the Holocene situation with its welldocumented "African humid period". However, differences in the evolution of the Holocene and the MIS 11 wet periods are noted. These findings corroborate pervious comparative studies from the higher latitudes indicating that the evolution of the MIS 11 interval was no strict analogue to the Holocene climate history and that care must be taken when using MIS 11 to estimate the future development of the recent interglacial conditions. The timing of climate evolution during full interglacial MIS 11 as documented in the subtropical Atlantic off Northwest Africa is remarkably coherent to the observations from the subpolar East Atlantic. This points to a close linkage between climate change at higher and lower latitudes that can be related to a persistent influence of atmospheric and oceanic variability of the highlatitude glacial-interglacial climate system between the subpolar ant the subtropical regions.

Acknowledgements. This manuscript benefited greatly from discussions with Rik Tjallingii and the careful reading and suggestions of two anonymous reviewers. The work was supported by the German Science Foundation.

Edited by: J. McManus 


\section{References}

Adkins, J., deMenocal, P., and Eshel, G.: The "African humid period" and the record of marine upwelling from excess $230 \mathrm{Th}$ in Ocean Drilling Program Hole 658C, Paleoceanography, 21, PA4203, doi:10.1029/2005PA001200, 2006.

Andersen, C., Koc, N., and Moros, M.: A highly unstable Holocene climate in the subpolar North Atlantic: evidence from diatoms, Quaternary Sci. Rev., 23, 2155-2166, 2004.

Bauch, H. A.: Paleoceanography of the North Atlantic Ocean $\left(68^{\circ}-76^{\circ} \mathrm{N}\right)$ during the past $450 \mathrm{ky}$ deduced from planktic foraminiferal assemblages and stable isotopes, in: Contributions to the Micropaleontology and Paleoceanography of the Northern North Atlantic, edited by: Hass, H. C. and Kaminski, M. A., Grzybowski Foundation Special Publication, 83-100, 1997.

Bauch, H. A. and Erlenkeuser, H.: Implications of subarctic deepwater foraminiferal $\delta^{18} \mathrm{O}$ for interpreting glacial-interglacial changes in sea level/ice volume and climate, in: Earth's climate and orbital eccentricity: The Marine Isotope Stage 11 question, edited by: Droxler, A., Poore, R., Burkle, L., and Osterman, L., AGU Monograph Series, 87-102, 2003.

Bauch, H. A., Erlenkeuser, H., Helmke, J. P., and Struck, U.: A paleoclimatic evaluation of marine oxygen isotope stage 11 in the high Northern Atlantic (Nordic seas), Global Planet. Change, 24, 27-39, 2000.

Bauch, H. A., Erlenkeuser, H., Spielhagen, R. F., Struck, U., Matthiessen, J., Thiede, J., and Heinemeier, J.: A multiproxy reconstruction of the evolution of deep and surface waters in the Nordic seas over the last 30000 years, Quaternary Sci. Rev., 20, 659-678, 2001.

Bauch, H. A. and Kandiano, E. S.: Evidence for early warming and cooling in North Atlantic surface waters during the last interglacial, Paleoceanography, 22, PA1201, doi:10.1029/2005PA001252, 2007.

Berger, A. and Loutre, M. F.: Modelling the climate response to astronomical and $\mathrm{CO}_{2}$ forcings, C. R. Acad. Sci. Paris, 323, 116, 1996.

Berger, A. L.: Long-term variations of caloric insolation resulting from the Earth's orbital elements, Quaternary Res., 9, 139-167, 1978.

Billups, K., Chaisson, W., Worsnopp, M., and Thunell, R.: Millennial-scale fluctuations in subtropical northwestern Atlantic durface ocean hydrography during the mid-Pleistocene, Paleoceanography, 19, PA2017, doi:10.1029/2003PA000990, 2004.

Billups, K., Lindley, C., Fisler, J., and Martin, P.: Mid Pleistocene climate instability in the subtropical northwestern Atlantic, Global Planet. Change, 54, 251-262, 2006.

Bond, G., Showers, W., Cheseby, M., Lotti, R., Almasi, P., deMenocal, P., Priore, P., Cullen, H., Hajdas, I., and Bonani, G.: A pervasive millennial-scale cycle in North Atlantic Holocene and glacial sediments, Science, 278, 1257-1266, 1997.

Broecker, W. S. and Stocker, T. F.: The Holocene $\mathrm{CO}_{2}$ rise: Anthropogenic or natural?, EOS Trans. AGU, 87, 27, 2006.

Carlson, T. N. and Prospero, J. M.: The large-scale movement of Saharan air outbreakes over the northern equatorial Atlantic, J. Appl. Meteor., 11, 283-297, 1972.

Crucifix, M. and Berger, A.: How long will our interglacial be?, EOS Trans. AGU, 87, 352-353, 2006.

de Abreu, L., Abrantes, F., Shackleton, N., Tzedakis, P. C., Mc-
Manus, J. F., Oppo, D. W., and Hall, M. A.: Ocean climate variability in the eastern North Atlantic during interglacial marine isotope stage 11: A partial analogue for the Holocene?, Paleoceanography, 20, PA3009, doi:10.1029/2004PA001091, 2005.

deMenocal, P.: Plio-Pleistocene African climate, Science, 270, 5359, 1995.

deMenocal, P., Ortiz, J., Guilderson, T., Adkins, J., Sarnthein, M., Baker, L., and Yarusinsky, M.: Abrupt onset and termination of the African Humid Period: rapid climate responses to gradual insolation forcing, Quaternary Sci. Rev., 19, 347-361, 2000.

deMenocal, P., Ortiz, J., Guilderson, T., and Sarnthein, M.: Coherent high- and low-latitude climate during the Holocene warm period, Science, 288, 2198-2202, 2000.

Eglinton, G., Bradshaw, S. A., Rosell, A., Sarnthein, M., Pflaumann, U., and Tiedemann, R.: Molecular record of secular sea surface temperature changes on 100-year timescale for glacial terminations I, II, and IV, Nature, 356, 423-425, 1992.

EPICA: Eight glacial cycles from an Antarctic ice core, Nature, 429, 623-628, 2004.

Firth, J. V., Blum, P., Lindblom, S., Michels, K., Sager, W. W., and Winkler, A.: Site 958, in: Proceedings of the Ocean Drilling Program, Initial Reports, edited by: Firth, J. V., College Station, TX, 3-13, 1996.

Ganssen, G.: Dokumentation von küstennahem Auftrieb anhand stabiler Isotopen in rezenten Foraminiferen vor NordwestAfrika, Meteor Forsch. Ergebnisse, C 37, 1-46, 1983.

Ganssen, G. and Kroon, D.: The isotopic signature of planktonic foraminifera from NE Atlantic surface sediments: implications for the reconstruction of past oceanic conditions, J. Geol. Soc. London, 157, 693-699, 2000.

Gasse, F.: Hydrological changes in the African tropics since the Last Glacial Maximum, Quaternary Sci. Rev., 19, 189-211, 2000.

Gasse, F., Tehet, R., Durand, A., Gibert, E., and Fontes, J. C.: The arid-humid transition in the Sahara and the Sahel during the last deglaciation, Nature, 346, 141-146, 1990.

Hastenrath, S.: Climate and circulation of the tropics, D. Reidel, Boston, MA, 1985.

Haug, G. H., Hughen, K. A., Sigman, D. M., Peterson, L. C., and Röhl, U.: Southward migration of the Intertropical Convergence Zone through the Holocene, Science, 293, 1304-1308, 2001.

Healey, S. and Thunell, R.: Millennial-scale variability in western subtropical North Atlantic surface and deep water circulation during marine isotope stages 11 and 12, Paleoceanography, 19, PA2016, doi:10.1029/2003PA000925, 2004.

Hearty, P. J., Kindler, P., Cheng, H., and Edwards, R. L.: A +20 m middle Pleistocene sea-level highstand (Bermuda and the Bahamas) due to partial collapse of Antarctic ice, Geology, 27, 375378, 1999.

Helmke, J. P. and Bauch, H. A.: Comparison of glacial and interglacial conditions between the polar and the subpolar North Atlantic Region over the past five climate cycles, Paleoceanography, 18, 1036, doi:10.1029/2002PA000794, 2003.

Hillaire-Marcel, C., Riser, J., Rognon, P., Petit-Maire, N., Rosso, J. C., and Soulie-Marche, I.: Radiocarbon chronology of Holocene hydrologic changes in northeastern Mali, Quaternary Res., 20, 145-164, 1983.

Hodell, D. A., Charles, C. D., and Ninnemann, U. S.: Comparison of interglacial stages in the South Atlantic sector of the southern 
ocean for the past $450 \mathrm{kyr}$ : implications for Marine Isotope Stage (MIS) 11, Global Planet. Change, 24, 7-26, 2000.

Imbrie, J., Hays, J. D., Martinson, D. G., McIntyre, A., Mix, A. C., Morley, J. J., Pisias, N. G., Prell, W. L., and Shackleton, N. J.: The orbital theory of Pleistocene climate: Support from a revised chronology of the marine $\delta^{18} \mathrm{O}$ record, in: Milankovitch and Climate, edited by: Berger, A. L., Imbrie, J., Hays, J. D., Kukla, G., and Saltzman, B., D. Reidel Publishing Company, Dordrecht, 269-305, 1984.

Johnson, J. and Stevens, I.: A fine resolution model of the eastern North Atlantic between the Azores, the Canary Islands and the Gibraltar Strait, Deep-Sea Res., 47, 875-899, 2000.

Jolly, D., Harrison, S. P., Damnati, B., and Bonnefille, R.: Simulated climate and biomes of Africa during the late quaternary: comparison with pollen and lake status data, Quaternary Sci. Rev., 17, 629-657, 1998.

Kandiano, E. S. and Bauch, H. A.: Phase relationship and surface water mass change in the Northeast Atlantic during marine isotope stage 11 (MIS 11), Quaternary Res., 68, 445-455, 2007.

King, A. L. and Howard, W. R.: Middle Pleistocene sea-surface temperature change in the southwest Pacific Ocean on orbital and suborbital scales, Geology, 28, 659-662, 2000.

Koc, N., Jansen, E., and Haflidason, H.: Paleoceanographic reconstructions of surface ocean conditions in the greenland, Iceland and Norwegian Seas through the last $14 \mathrm{ka}$ based on diatoms, Quaternary Sci. Rev., 12, 115-140, 1993.

Koopmann, B.: Saharastaub in den Sedimenten des subtropischtropischen Nordatlantik während der letzten 20000 Jahre, Christian-Albrechts-Universität, Kiel, 108 pp., 1979.

Kroon, D., Alexander, I., Little, M., Lourens, L. J., Matthewson, A., Robertson, A. H. F., and Sakamoto, T.: Oxygen isotope and sapropel stratigraphy in the eastern Mediterranean during the last 3.2 million years, in: Proceedings of the Ocean Drilling Program, Scientific Results, edited by: Robertson, A. H. F., Emeis, K.-C., Richter, C., and Camerlenghi, A., College Station, TX, 181-189, 1998.

Kutzbach, J. E. and Liu, Z.: Response of the African Monsoon to Orbital Forcing and Ocean Feedbacks in the Middle Holocene, Science, 278, 440-443, 1997.

Lange, H.: Distribution of chlorite and kaolinite in eastern Atlantic sediments off North Africa, Sedimentology, 29, 427-432, 1982.

Lourens, L. J.: Revised tuning of Ocean Drilling Program Site 964 and KC01B (Mediterranean) and implications for the $\delta^{18} \mathrm{O}$, tephra, calcareous nannofossil, and geomagnetic reversal chronologies of the past 1.1 Myr, Paleoceanography, 19, PA3010, doi:10.1029/2003PA000997, 2004.

Loutre, M. F. and Berger, A.: Marine isotope stage 11 as an analogue for the present interglacial, Global Planet. Change, 36, 209-217, 2003.

Marchal, O., Cacho, I., Stocker, T. F., Grimalt, J. O., Calvo, E., Martrat, B., Shackleton, N., Vautravers, M., Cortijo, E., van Kreveld, S., Andersson, C., Koc, N., Chapman, M., Sbaffi, L., Duplessy, J.-C., Sarnthein, M., Duprat, J., and Jansen, E.: Apparent long-term cooling of the sea-surface in the northeast Atlantic and Mediterranean during the Holocene, Quaternary Sci. Rev., 21, 455-483, 2002.

Matthewson, A. P., Shimmield, G. B., Kroon, D., and Fallick, A. E.: A 300 kyr high-resolution aridity record of the North African continent, Paleoceanography, 10, 677-692, 1995.
McManus, J. F., Oppo, D. W., Cullen, J. L., and Healey, S.: Marine isotope stage 11 (MIS 11): Analog for Holocene and future climate?, in: Earth's climate and orbital eccentricity: The Marine Isotope Stage 11 question, edited by: Droxler, A., Poore, R. Z., and Burckle, L., AGU Monograph Series, Washington, D.C., 69-85, 2003.

Mercone, D., Thomson, J., Abu-Zied, R. H., Croudace, I. W., and Rohling, E. J.: High-resolution geochemical and micropalaeontological profiling of the most recent eastern Mediterranean sapropel, Mar. Geol., 177, 25-44, 2001.

Oppo, D. W., McManus, J. F., and Cullen, J. L.: Abrupt climate events 500000 to 340000 years ago: evidence from subpolar North Atlantic sediments, Science, 279, 1335-1338, 1998.

Parkin, D. W. and Shackleton, N.: Trade wind and temperature correlations down a deep-sea core off the Sahara coast, Nature, 245, 455-457, 1973.

Pflaumann, U., Sarnthein, M., Ficken, K., Grothmann, A., and Winkler, A.: Variations in eolian and carbonate sedimentation, seasurface temperature, and productivity over the last 3 m.y. at Site 958 off Northwest Africa, in: Proceedings of the Ocean Drilling Program, Scientific Results, edited by: Firth, J. V., College Station, TX, 3-16, 1998.

Prospero, J. M. and Lamb, P. J.: African Droughts and Dust Transport to the Caribbean: Climate Change Implications, Science, 302, 1024-1027, 2003.

Röhl, U. and Abrams, L. J.: High-resolution, downhole, and nondestructive core measurements from Sites 999 and 1001 in the Caribbean Sea: application to the Late Paleocene Thermal Maximum, in: Proceedings of the Ocean Drilling Program, Scientific Results, edited by: Leckie, R. M., Sigurdsson, H., Acton G. D., and Draper, G., College Station, Texas, 191-203, 2000.

Rohling, E. J., Fenton, M., Jorissen, F. J., Bertrand, P., Ganssen, G., and Caulet, J. P.: Magnitudes of sea-level lowstands of the past 500000 years, Nature, 394, 162-165, 1998.

Rohling, E. J., Jorissen, F. J., and De Stigter, H. C.: 200 year interruption of Holocene sapropel formation in the Adriatic Sea, J. Micropaleontology, 16, 97-108, 1997.

Ruddiman, W. F.: The anthropogenic greenhouse era began thousands of years ago, Climatic Change, 61, 261-263, 2003.

Ruddiman, W. F.: The early anthropogenic hypothesis a year later, Climatic Change, 69, 427-434, 2005.

Ruddiman, W. F.: The early antropogenic hypothesis: Challenges and responses, Rev. Geophys., 45, RG4001, doi:10.1029/2006RG000207, 2007.

Ruddiman, W. F. and Janecek, T.: Pliocene-Pleistocene biogenic and terrigenous fluxes at equatorial Atlantic Sites 662, 663, and 664, in: Proceedings of the Ocean Drilling Program, Scientific Results, edited by: Baldauf, G., Heat, G. R., Ruddiman, W. F., and Sarnthein, M., College Station, TX, 211-240, 1989.

Sarnthein, M. and Tiedemann, R.: Younger Dryas-style cooling events at glacial Terminations I-VI at ODP Site 658: Associated benthic $\delta^{13} \mathrm{C}$ anomalies constrain meltwater hypothesis, Paleoceanography, 5, 1041-1055, 1990.

Sarnthein, M., Thiede, J., Pflaumann, U., Erlenkeuser, H., Fütterer, H., Koopmann, B., Lange, H., and Seibold, E.: Atmospheric and ocean circulation patterns off Northwest Africa during the past 25 million years, in: Geology of the Northwest African continental margin, edited by: von Rad, U., Hinz, K., Sarnthein, M., and Seibold, E., Springer Verlag, Berlin, 545-604, 1982. 
Schütz, L., Jaenicke, R., and Pietrek, H.: Saharan dust transport over the North Atlantic Ocean, Geol. Soc. Am. Special Paper, 186, 87-100, 1981.

Shackleton, N.: Oxygen isotope analysis and Pleistocene temperature reassessed, Nature, 215, 15-17, 1967.

Siegenthaler, U., Stocker, T. F., Monnin, E., Lüthi, D., Schwander, J., Stauffer, B., Raynaud, D., Barnola, J.-M., Fischer, H., Masson-Delmotte, V., and Jouzel, J.: Stable carbon cycle-climate relationship during the Late Pleistocene, Science, 310, 13131317, 2005.

Stuut, J.-B. W., Zabel, M., Ratmeyer, V., Helmke, P., Schefuß, E., Lavik, G., and Schneider, R. R.: Provenance of presentday eolian dust collected off NW Africa, J. Geophys. Res., 110, DO4202, doi:10.1029/2004JD005161, 2005.
Thunell, R. C., Poli, M. S., and Rio, D.: Changes in deep and intermediate water properties in the western North Atlantic during marine isotope stages 11-12: evidence from ODP Leg 172, Mar. Geol., 189, 63-77, 2002.

Tiedemann, R., Sarnthein, M., and Shackleton, N. J.: Astronomic timescale for the Pliocene Atlantic $\delta^{18} \mathrm{O}$ and dust flux of Ocean Drilling Program site 659, Paleoceanography, 9, 619-638, 1994.

Weldeab, S., Lea, D. W., Schneider, R. R., and Andersen, N.: 155000 years of West African Monsoon and ocean thermal evolution, Science, 316, 1303-1307, 2007. 